\title{
DINÂMICA DE CRESCIMENTO DA AVEIA PRETA SOB DIFERENTES DOSES DE NITROGÊNIO E AJUSTE DE MODELO MATEMÁTICO DE RENDIMENTO POTENCIAL EM FUNÇÃO DE PARÂMETROS CLIMÁTICOS
}

\author{
Sérgio José Alves \\ Orientador: Prof. Dr. Aníbal de Moraes
}

\begin{abstract}
RESUMO
Visando estudar a dinâmica de crescimento da aveia preta (Avena strigosa Lam.), cultivar IAPAR 61, sob diferentes níveis de nitrogênio $(0 ; 75 ; 150 ; 225$ e $300 \mathrm{~kg} / \mathrm{ha})$ e ajustar um modelo matemático de rendimento potencial de forragem baseado no acúmulo térmico e na radiação solar incidente, foi conduzido um trabalho na estação experimental da Universidade Federal do Paraná - UFPR, múnicípio de Pinhais-PR. A semeadura foi realizada em 19 de abril de $1999 \mathrm{com} 60 \mathrm{~kg}$ de sementes $/ \mathrm{ha}$, em linhas espaçadas de $17 \mathrm{~cm}$. O experimento foi irrigado e mantido livre de invasoras e insetos. A adubação nitrogenada foi efetuada com uréia e parcelada em três aplicações ( 24,54 e 80 dias após a emergência das plantas). A produção de forragem foi avaliada em quatro cortes, sendo três efetuados durante a fase vegetativae um na fase reprodutiva das plantas. Foram feitas avaliações semanais de peso da matéria seca da parte aérea (MS), teor de nitrogênio na biomassa aérea $(\% \mathrm{~N})$, relação lâmina foliar/caule (LF:C) e índice da área foliar (IAF) e duas vezes por semana foram realizadas as medições de folhas e a contagem de perfilhos em plantas marcadas. O balanço de radiação foi realizado com base em dados coletados por um quantômetro e por sensores instalados nos diferentes tratamentos e de forma a avaliar a radiação incidente, refletida e transmitida. Houve uma significativa resposta da cultura a doses de nitrogênio e uma interação significativa destas com as épocas de corte. Observou-se menores produtividades na ausência de nitrogênio em todas as épocas avaliadas, com uma produção total de $3422.6 \mathrm{~kg}$ de MS/ha. A dose de $300 \mathrm{~kg}$ de N/ha possibilitou uma produção total de 9953,6 de MS/ha e destacou-se das demais durante a fase reprodutiva da cultura, enquanto que na fase vegetativa a máxima produtividade foi obtida com $225 \mathrm{~kg}$ de N/ha $(7268,7 \mathrm{~kg} \mathrm{MS} / \mathrm{ha})$. O nitrogênio modificou todas as características morfogênicas avaliadas: índice de área foliar (IAF), perfilhamento, relação lâmica foliar: colmo, comprimento foliar, taxas de elongação foliar e de senescência. A evolução do IAF nos dois primeiros acúmulos deveu-se tanto ao incremento do perfilhamento quanto do comprimento foliar, porém no terceiro corte a evolução deveu-se quase que exclusivamente à expansão foliar. O filocrono da aveia preta cultivar IAPAR61 foi de aproximadamente $80 \mathrm{GD}$ no afilho principal, independentemente da dose de nitrogênio utilizada. Os submodelos para estimativa da evolução do IAF baseados no acúmulo de graus-dia (GD), e da eficiência de absorção (Ea) baseado no coeficiente de extinção (K) e no sub-modelo de IAF, são adequados para a estimação da radiação fotossintéticamento absorvida (PARa) e para análise de crescimento da biomassa aérea baseada no uso da radiação, mas são diferentes para a fase de estabelecimento e para os rebrotes. O crescimento potencial da aveia preta IAPAR 61, em condições não limitantes, pode ser estimado por meio de um modelo simples com duas variáveis climáticas: radiação global incidente acumulada (Rs) e graus-dia acumulados (GD), de fácil obtenção em estações meteorológicas.
\end{abstract}

\begin{abstract}
Aiming at studying the growing dynamics of black oats (Avena strigosa Lam.) under several levels of nitrogen (O; 75; 150; 225 and $300 \mathrm{~kg} / \mathrm{ha}$ ), and to validate a mathematical model of potential yield of forage based on degree-days and incident solar radiation, a field experiment was carried out at the experimental station of Federal University of Paraná - UFPR, municipality of Pinhais, PR, Brazil. Sowing was made on April 19, 1999, with $60 \mathrm{~kg}$ of seeds/ha, in rows spaced by $17 \mathrm{~cm}$. The experiment was irrigated and kept free of weeds and pests. Nitrogen fertilization was made with urea split in three applications at 24, 54 and 84 days after plant emergence. Forage production was evaluated after four cuttings, with three during vegetative growth and one in the reproductive stage. Every week, the following evaluations were made: dry matter and nitrogen content $(\% \mathrm{~N}$ ) of the upper part; leaf blade / culm ratio, and leaf area index (LAl). Every two weeks leaves were measured and tillering were counted on selected plants. Photosynthetic Active Radiation (PAR) data were collected with PAR sensors installed in the treatments, stored in a CR-10 datalogger (Campbell Scientific), and PAR incident, reflected and transmitted. There was a significant response to nitrogen dosage and a significant interaction of dosage with cutting time. There was lower productivity in the absence of nitrogen in all cutting times evaluated, with an accumulated production of $3422.6 \mathrm{~kg}$ dry matter / ha. The treatment with $300 \mathrm{~kg} \mathrm{~N} / \mathrm{ha}$ provided 9953.6 $\mathrm{kg} /$ ha dry matter and was superior the all the others during the reproductive phase of the crop. During the vegetative phase the maximum productivity of $7268.7 \mathrm{~kg}$ dry matter / ha was obtained with $225 \mathrm{~kg} \mathrm{~N} / \mathrm{ha}$. Nitrogen modified all morphogenic traits evaluated: leaf area index, tillering, leaf blade / culm ratio, leaf length, leaf elongation rate and senescence. The evolution of leaf area index in the first two cuttings was related to both tillering increment and leaf length, but in the third cutting the evolution was mainly due to leaf expansion. The black oat philocron of the cultivar IAPAR 61 was approximately 80 degree-days for the main tiller independent of the nitrogen dosage. The submodels to estimate the evolution of LAl based on degree-days, and the absorption efficiency (Ea) based on the extinction coefficient (K) and on the submodel of $\mathrm{LAl}$, were suitable to estimate the absorved photosynthetically active radiation (PARa) and for growth analysis of biomass based on radiation, but they differed for the phase of plant establishment and re-growth. Potential growth of black oats IAPAR 61, under non-limiting conditions, can be estimated by a simple model with two climatic variables: accumulated global solar radiation and degree-days, easily available from weather stations.
\end{abstract}

Key-words: leaf area index (LAI); leaf bladelculm ratio; tillering; leaf length; nitrogen content; philocron; leaf elongation rate; leaf senescence rate. 